\title{
PSYCHE
}

VOL. XXV

FEBRUARY, 1918

No. 1

\section{THE GENUS NARNIA STAL, AND A KEY TO THE GENERA OF ANISOSCELINI A. AND S. (COREIDA: HETEROPTERA).}

\author{
By Edmund H. Gibson and Abby Holdridge, \\ Bureau of Entomology, Washington, D. C.
}

Members of the genus Narnia Stal present an interesting group in the tribe Anisoscelini A. and S. as well as presenting difficulties to the systematist. In 1862 Stal described the genus to include his femorata and later, in 1870, he described $N$. pallidicornis, both descriptions being made from single specimens. Since then three other well defined species have been added to the genus. Now, from the study of a large series of specimens it appears that Stal's two species are the same and one species, with the name femorata retained. The characters which he gives for separating pallidicornis from femorata can not be termed stable, such as the color of the basal joint of the antennæ, which varies to a considerable degree in nearly every species of the tribe. The late Mr. Otto Heidemann was of the same opinion as the present authors in this matter. Mr. E. P. Van Duzee, Entomological News, Vol. XVII, No. 10, pp. 384, 1906, has also voiced a similar belief when he stated that he suspected femorata to be a northern form of pallidicornis.

Mr. Van Duzee considers his species snowi and wilsoni as forming a subgenus to which he gives the name Xerocoris. In this respect the authors disagree with Mr. Van Duzee and state that if there is to be any dividing of the genus it should be so as to group femorata and snowi together and inornata and wilsoni together. Such a grouping would be based upon the form of the dilation of the hind tibiæ which is quite generally accepted to be of greater importance than the relative breadth of insect and connexium, and form of prothorax. It seems quite unnecessary to recognize subgenera in Narnia. 


\section{Narnia Stal.}

Narnia Stal, Stett. Ent. Zeit., Vol. 23, p. 294 (1862).

Head elongate, horizontal. Antennæ rather stout but not swollen or dilated, basal joint short, shorter than length of head; rostrum passing the metasternum, bucculæ short. Thorax longer than head, broad and rounding posteriorly. Elytra narrowing towards apex. Hind femora more or less swollen, hind tibiæ with small dilations or foliations. Narnia may be separated from Leptoglossus by the smaller dilation of the hind tibiæ and shorter basal joint of antennæ.

Key to the Species.

1. Dilation of hind tibia reaches two-thirds the length of tibia....2 Dilation of hind tibia reaches three-fourths the length of tibia. . 3

2. Elytra with distinct, broad, white band; width comparatively great........................... snowi Van D.

Elytra without distinct white band, sometimes a slight trace of one; width comparatively narrow..........femorata Stal

3. Species small, apex of head, basal joint of antennæ, and legs red................................

Species larger, no distinct red colorations...... inornata Dist.

\section{Narnia femorata Stal.}

Narnia femorata Stal, Stett. Ent. Zeit., Vol. 23, p. 296 (1862). Narnia pallidicornis Stal, Enum., I, p. 166 (1870).

This species can be distinguished from all others by the short stout dilation on the hind tibiæ and without band across elytra.

The species occurs in California, Arizona, Texas, Mexico and Guatemala.

\section{Narnia snowi Van D.}

Narnia snowi Van Duzee, Ent. News, Vol. XVII, No. 10, p. 384 (1906).

The distinct broad white band across the elytra and broader form will readily distinguish this species from femorata Stal.

It is recorded from California, Arizona and New Mexico.

Narnia inornata Dist.

Narnia inornata Distant, Biol. Cent. Amer., Vol. I (1880-93).

This species may be readily distinguished by the long slender dilations of the hind tibiæ, and lack of reddish colorations.

This western species occurs in Arizona, California and Mexico. 
Narnia wilsoni Van D.

Narnia wilsoni Van Duzee, Ent. News, Vol. XVII, No. 10, p. 384 (1906).

Wilsoni differs from all other species in that it is much smaller, and has red colorations on apex of head, basal joint of antennæ, and legs.

This species occurs in California.

A Key to the Genera of Anisoscelini A. and S.

The following key includes all of the genera of the tribe Anisoscelini A. and S. Representatives of but three of the genera, Chrondrocera Lap., Leptoglossus Guer. and Narnia Stal occur in American north of Mexico, the other genera being limited to Central and South America.

The tribe may be characterized as follows: Head elongate, antennæ long and more or less slender. Thorax trapezoidal in form, greatly depressed anteriorly, posterior lateral angles more or less acutely angled. Posterior femora sometimes swollen but not incrassated. Posterior tibiæ with a broad thin dilation or foliation which is often wider than the width across the elytra.

The genera may be considered as grouped into two divisions, Anisoscelaria n. n. those having the joints of the antennæ simple as in Anisoscelis and Chrondroceraria n. n. those having the joints of the antennæ more or less dilated as in Chrondrocera.

The authors feel justified in placing Stenoscelidea within this tribe as the characters of the hind tibiæ are of greater importance than the form of the antennæ.

1. First joint of the antennæ much longer than the second

Uranocoris Walk.

First segment of the antennæ not longer than the second, often much shorter...........................

2. Segments of antennæ prominently dilated...........8

Segments of antennæ not dilated ................ 3

3. Basal joint of antennæ short, shorter than length of head

Narnia Stal

Basal joint of antennæ long, as long or longer than length of head .............................. 4

4. Basal joint of antennæ equal to length of head, or slightly longer.......................Leptoglossus Guér.

Basal joint of antennæ very much longer than length of head, 5 
5. First and fourth segments of antennæ incrassated

Microphyilia Stal

First and fourth segments of antennæ not incrassated......6

6. Width of dilation of posterior tibiæ less than width across elytra........................ Stenoscelidea Hope.

Width of dilation of posterior tibiæ greater than width across elytra............................ 7

7. Length of basal joint of antennæ less than twice the length of

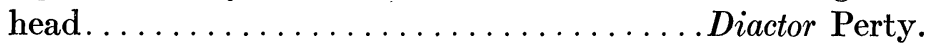

Length of basal joint of antennæ at least twice the length of head.......................... Anisoscelis Latr.

8. Second segment of antennæ dilated, third also dilated . . . ...9 Second segment of antennæ simple, third dilated, Baldus Stal

9. Second segment of antennæ dilated on both sides

Chrondrocera Lap.

Second segment of antennæ slightly dilated above, not below, 10

10. Posterior lateral angles of thorax produced, or sharply angled Holymenia Stal

Posterior lateral angles of thorax not at all produced........

Tarpeius Stal

\section{A PHYLOGENETIC STUDY OF THE TERGA AND WING BASES IN EMBIIDS, PLECOPTERA, DERMAPTERA, AND COLEOPTERA. ${ }^{1}$}

By G. C. Crampton, Ph.D.,

Massachusetts Agricultural College, Amherst, Mass.

In a previous paper, the Plecoptera, Embiids, Hemimerids, and Dermaptera, were grouped in a superorder called the Panplecoptera, and a further study would indicate that the Coleoptera might be included in this group also. There is some doubt as to the Strepsiptera, but certain features point to a rather close relationship between them and the Coleoptera (as is generally thought to be the case, although the investigations of Pierce, 1909, have thrown some doubt upon the current idea of their affinities) and it is quite possible that the Strepsiptera should likewise be included in the superorder mentioned above.

1 Contribution from the Entomological Laboratory of the Massachusetts Agricultural College, Amherst, Mass. 

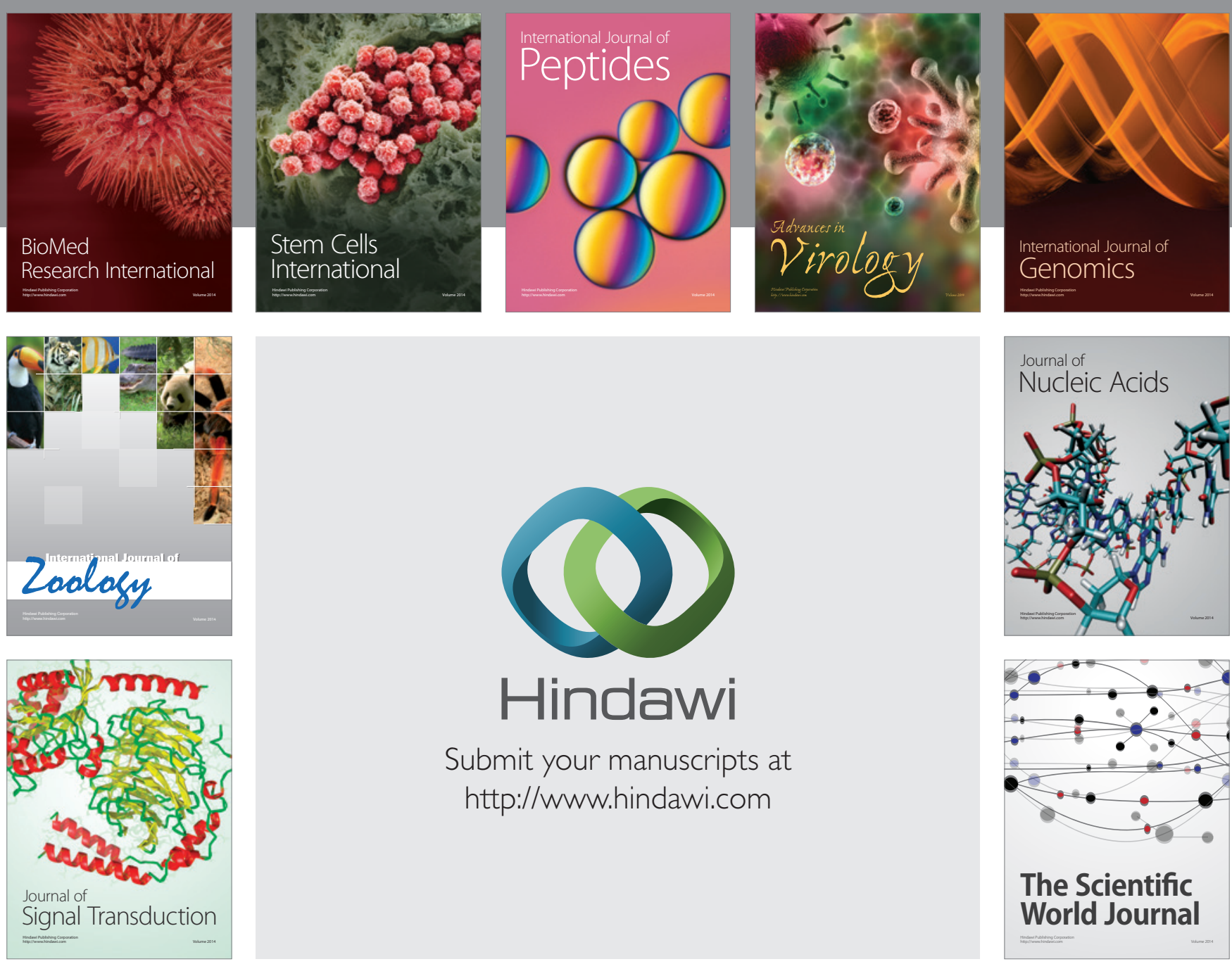

Submit your manuscripts at

http://www.hindawi.com
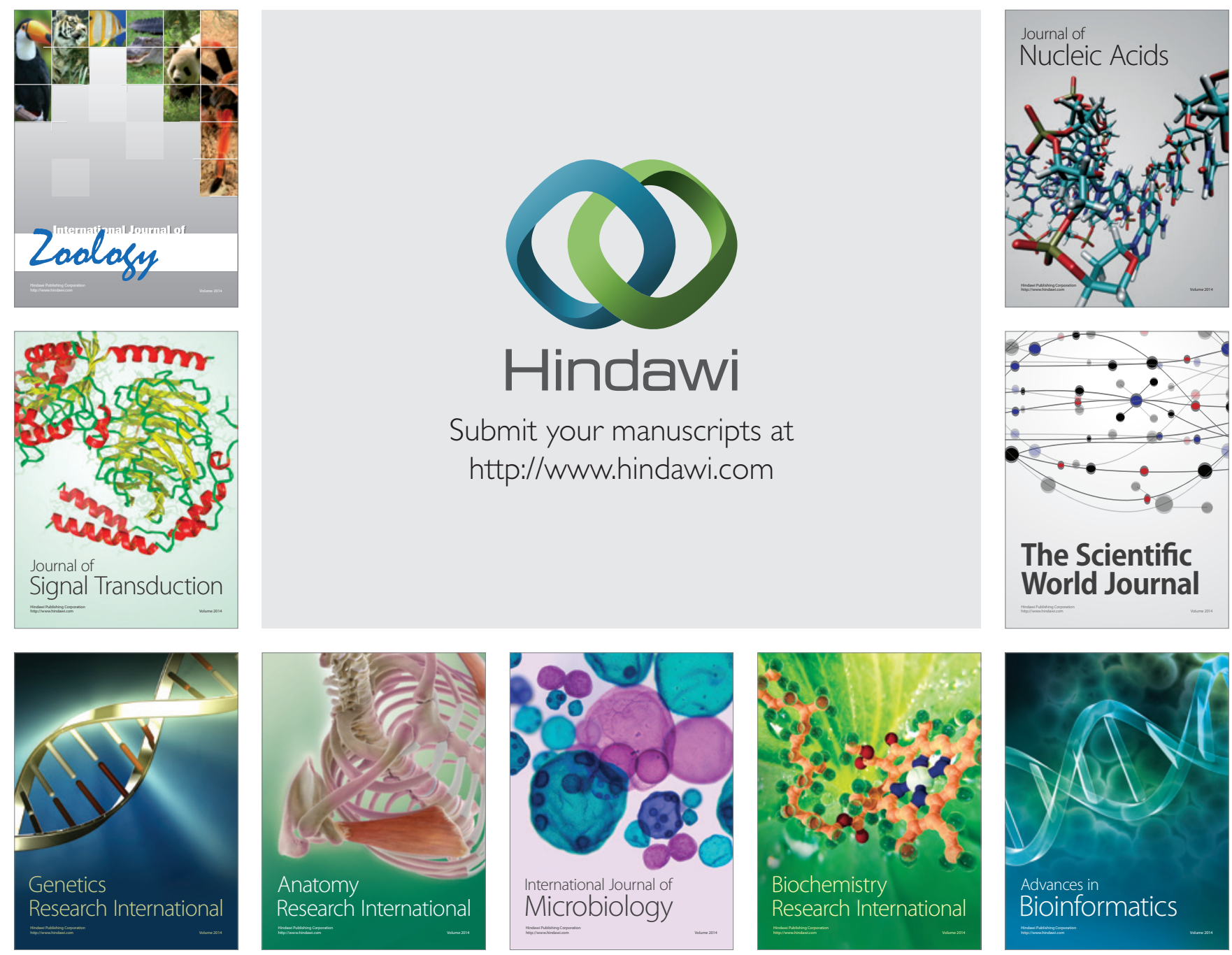

The Scientific World Journal
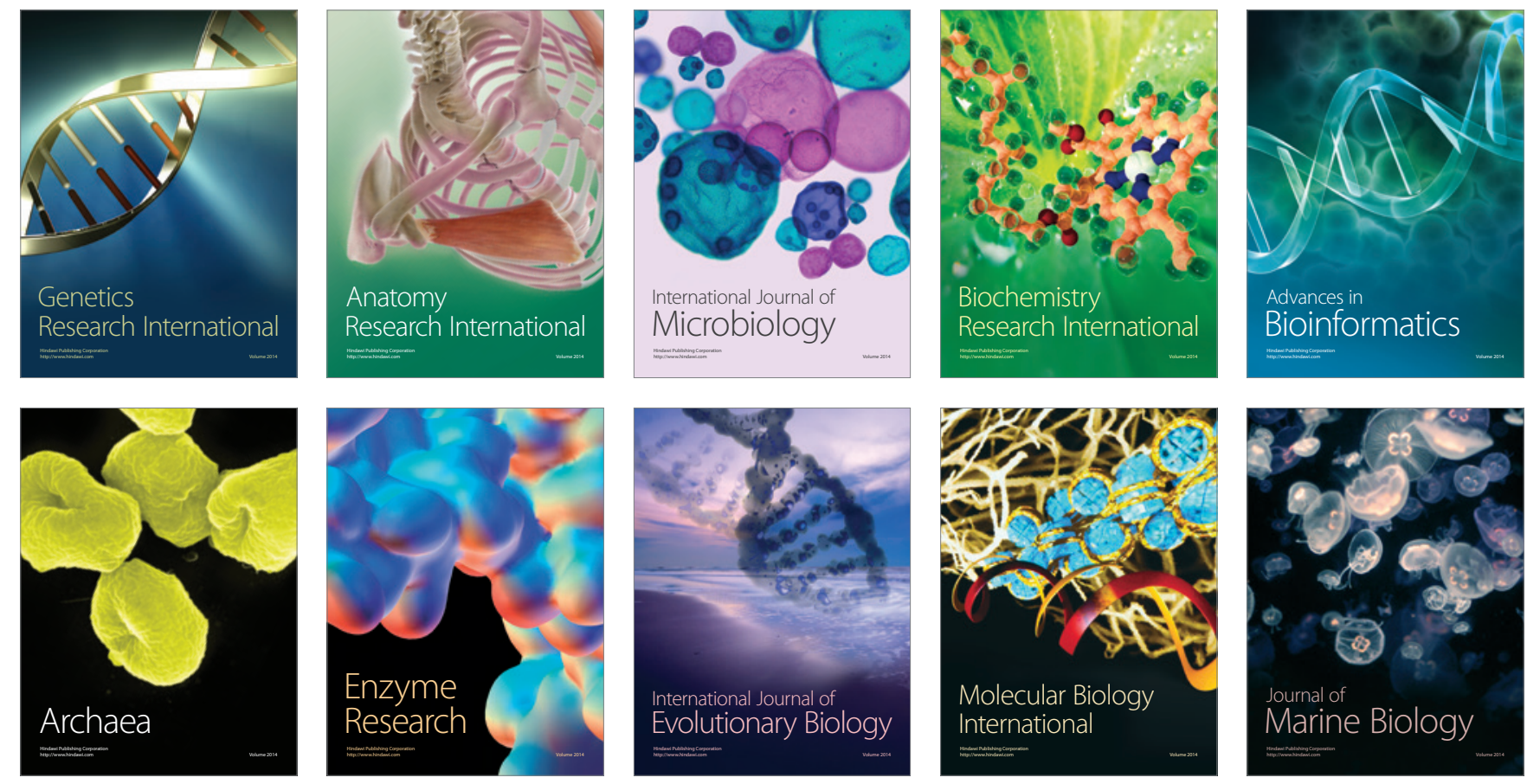